\title{
AGRICULTURE AND CLIMATE IN CENTRAL OTAGO
}

\section{G.G. COSSENS}

Invermay Agricultural Centre, MAF, Mosgiel

Abstract

The variation and individuality of Central Otago result from a unique combination of climate and topography. The range and basin structures produce New Zealand's nearest approach to a "Continental" Climate, and on a yearly basis Central Otago can be one of the driest as well as one of the hottest and coldest areas in the country. There are two unique features. The first a dry central core with horticulture as a dominant activity. The second is a high pastoral plateau, the East Otago Plateau, from 400 to 900 metres altitude, marking the Eastern boundary of Central Otago.

The agricultural pattern is traditional but it is suggested there is scope for other non traditional crops. Of all the physical elements surveyed in the past, e.g.rock or soil type, slope or vegetation, there is frequently no reference to climate. However, the resource value of any locality awes from its particular local climate or "topoclimate". Climate when regarded as such requires a new approach to data gathering. Research in Central Otago aims to increase our knowledge of topoclimate on the valley floors and locate special microclimates suitable for possible and existing horticultural crops and at the same time remove some of the hazards.

\section{Keywords: topoclimate}

\section{ELEMENTS OF LANDSCAPE AND CLIMATE}

It is now over 20 years since Maunder (1965) wrote his comprehensive summary of climate in Central Otago. On a year to year basis, he comments, Central Otago is usually one of the driest, coldest as well as one of the hottet areas in New Zealand. Almost bisected by the 45th parallel it lies within an $80 \mathrm{~km}$ radius on Alexandra as focus. The region (Figure 1) is the distinctive product of its topography which in turn gets its character from the almost universal presence of a basement schist rock. The schist, warped and block faulted into a series of north west or south west oriented ranges and basins, has been weathered into the fretted and tor landscapes unique in New Zealand.

If Central Otago is divided into four quarters, fivedistrict regions emerge. On the north west perimeter are the Western Ranges, $2000 \mathrm{~m}$ in altitude; in the north east are the Northern Uplands of $1800 \mathrm{~m}$; in the south west the $1500 \mathrm{~m}$ Southern Ranges; and in the south east the extensive East Otago Plateau 400 to $900 \mathrm{~m}$ in altitude. The fifth element is a Central Core some $65 \mathrm{~km}$ in radius on Alexandra, with generally over 2000 hours of sunshine and including most of the populated areas, usually in the valleys of the range and basin structures and below $500 \mathrm{~m}$ altitude.

The surrounding shield of mountains produces a marked rainshadow effect, a semi-arid central core and New Zealand's nearest approach to a continental climate. However, the whole region is not semi-arid and as rainfall increases the moisture regime becomes sub-humid, humid or even superhumid near the Southern Alps. The warmer parts of the semi-arid and sub-humid zones have horticulture as a dominant pursuit; the cooler sub-humid and humid zones are given over to pastoral farming, whilst the high altitude cold zones (above $1500 \mathrm{~m}$ ) have recently seen winter sports as a major activity far surpassing pastoratism. In many cases the high price of land in the warm valley floors is a price paid for high quality climate - not high quality soils. There is a need then to present objectively based data to ensure subjective feelings do not misrepresent the climatic character.

\section{THE THERMAL REGIME}

Air temperature records at Dunedin date from 1865, those from Alexandra from 1929. Mean annual temperatures at Dunedin show a distinct trend towards steadily 


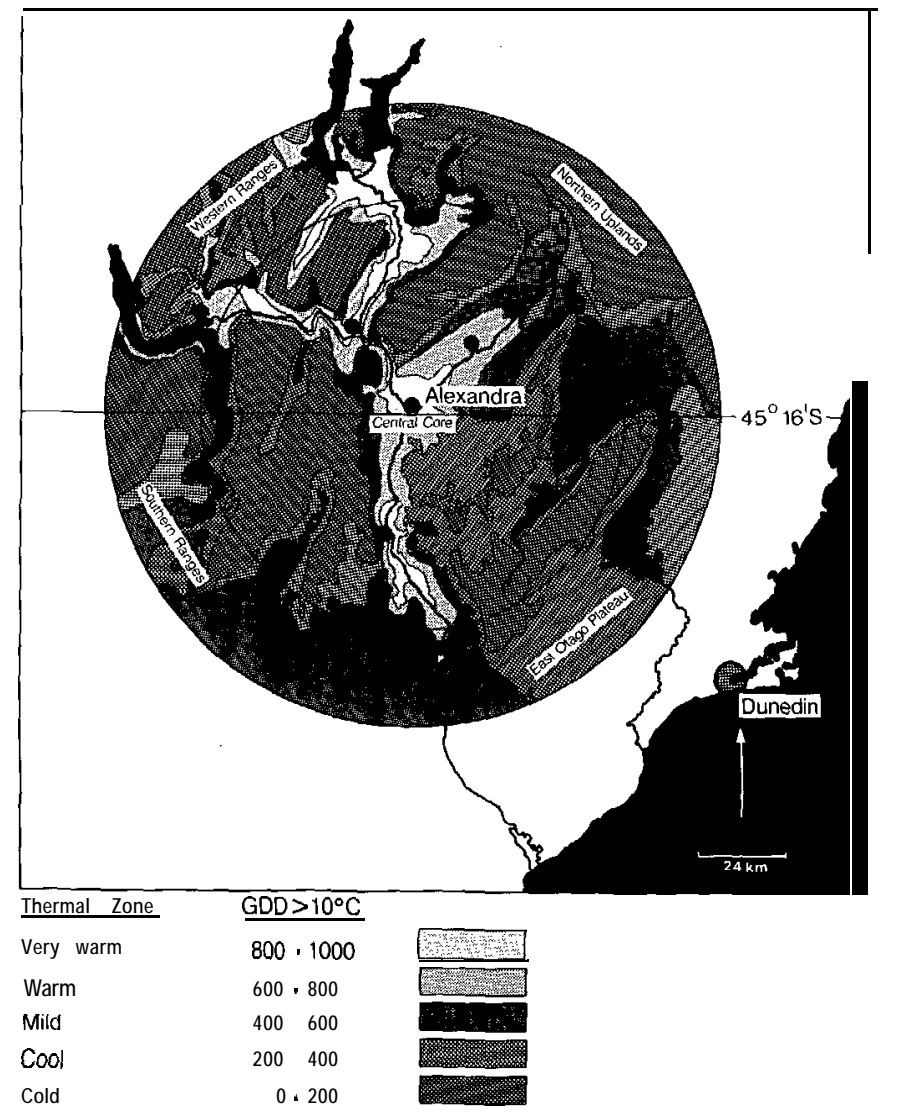

Figure 1: Thermal Zones of Central Otago.

rising temperatures over the 120 year period from 1865 to 1985 (Figure 2). The increase in mean annual temperature of almost $1{ }^{\circ} \mathrm{C}$ since 1900 is shown clearly by the 10 year running means. When the record at Alexandra is compared with Dunedin the temperature variations are similar. Salinger and Gunn (1975) and Trenberth (1979) point out that the trend is typical over the whole of New Zealand. Dunedin temperature variation can therefore be used as a fair indication of climatic conditions over the Central Otago region, at least as far back as 1865. Climatic deterioration occurred over the two decades 7880 to 7900 and the period 1900 to 1935 was the coldest over the country in recorded history. The period 1965 to 1985 was one of general warmth with mild winters and little ice for winter sports activities on the main Central Otago irrigation dams. It was also a period, particularly from 1975 to 1980 , when fungal diseases badly affected lucerne, probably as a result of mild wet winters, in the previously fairly disease free semi-arid zone.

Warm season growing degree days (GDD) are a convenient way of expressing the thermal character. Over all of Central Ctago there is little plant activity in the cool season from May to October. The warm season from November to April is therefore 


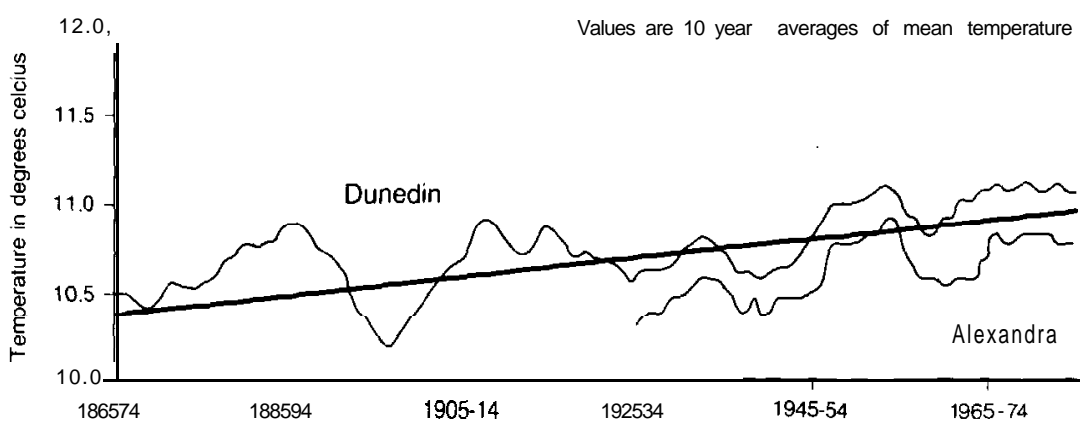

Figure 2: Dunedin and Alexandra Temperatures.

particularly useful as an index of plant performances as it represents the period of active plant growth. The base chosen of $10^{\circ} \mathrm{C}$ is practical, being the approximate lower limit for pip and stone fruit growth and also for clover growth so important in realising tussock grassland potential.

Five thermal regions can be recognised on this basis in Central Otago: namely, O-ZOO GDD, 200-400; 400-600; 600-800; 800-1000. Clover growth is low below 200 GDD, cereals will doubtfully mature below 300; pip fruits are unsatisfactory below 600 , and stone fruits below 800; it takes about 1000 GDD to produce a good white wine.

During the warm season there is a continental warming effect on the inner core which compensates for and reduces the temperature lapse rate, that is the decline in temperature with increasing altitude, expressed as ${ }^{\circ} \mathrm{C} / 100 \mathrm{~m}$ (the reverse of course occurs in the cooler season with a marked chilling). The sum total of this warming means that warm season temperatures are much higher inland than the equivalent easterly coastal sites (Table 1).

Table 1' Warm season growing degree days greater than $10^{\circ} \mathrm{C}$ for sites at similar altitudes but increasing distance from coast.

\begin{tabular}{lccc}
\hline Site & $\begin{array}{c}\text { Altitude } \\
(\mathrm{m})\end{array}$ & $\begin{array}{r}\text { Distance from coast } \\
(\mathbf{k m})\end{array}$ & $\begin{array}{c}\text { GDD } \\
\left(>10^{\circ} \mathrm{C}\right)\end{array}$ \\
\hline Deep Stream & 390 & 40 & 314 \\
Patearoa & 380 & 60 & 550 \\
Hawea Flat & 350 & 150 & 866 \\
\hline
\end{tabular}

Valley Floors

The most notable effect is the large diurnal and seasonal range of temperature and within the central core an extreme range between highest and lowest temperatures of $45^{\circ} \mathrm{C}$. The average daily maximum temperature at Cromwell in January of $24.4^{\circ} \mathrm{C}$ is one of the highest in New Zealand and compares with Gisborne $24.4^{\circ} \mathrm{C}$ and Hastings $25.4^{\circ} \mathrm{C}$. On the other hand Ophir has one of the lowest recorded air temperatures for a populated area of New Zealand of $-19.6^{\circ} \mathrm{C}$.

\section{Mountain Ranges}

Temperatures decrease with altitude and the lapse rate varies from 0.3 to $0.6^{\circ} \mathrm{C} / 100 \mathrm{~m}$ depending on aspect, season and proximity to the coast. Generally lapse rates are higher in spring and summer than winter and are higher at altitudes above 1000 metres than below (Mark 1965, Cossens 1982).

Where warm season $\mathrm{GDD}>10^{\circ} \mathrm{C}$ are less than 200 it is more relevant from the pasture (grass) production aspect to look at $\mathrm{GDD}>5^{\circ} \mathrm{C}$. At altitudes above $750 \mathrm{~m}$ the number of days warmer than $5^{\circ} \mathrm{C}$ and less than $10^{\circ} \mathrm{C}$ is vitally important for grass growth, clover growth is almost negligible below $10^{\circ} \mathrm{C}$. 


\section{PRECIPITATION}

The term semi-arid is usually applied in Central Otago to areas where the precipitation is from $300-450 \mathrm{~mm}$; sub humid 450.750 , humid $750-1500$ and superhumid, greater than $1500 \mathrm{~mm}$.

Most rainbearing situtations in Central Otago result from cold fronts with westerly or south westerly winds (Browne 1959). Because of the sheltering effect of the surrounding ranges precipitation on the valley floors is limited, nevertheless the mountain slopes show strong rainfall gradients and rainfall patterns can vary markedly within a few kilometres. Athough Central Otago is generally regarded as being dry it does in fact have a vertical and horizontal rainfall range from about 350 to $1500 \mathrm{~mm}$. The dry heart about Alexandra and Cromwell has less than $400 \mathrm{~mm}$ rainfall whilst the head of Lakes Wanaka and Hawea exceeds $1500 \mathrm{~mm}$, as do most of the mountain ranges above $1200 \mathrm{~m}$ altitude.

Whilst there is a very strong long term trend of increasing temperature over a period of 120 years it is not pronounced with precipitation (Salinger \& Gunn 1975).

\section{Valley Floors}

Alexandra besides having the lowest mean annual precipitation in New Zealand also has the lowest recorded for any year $(211 \mathrm{~mm})$ or for any consecutive 12 month period $(167 \mathrm{~mm})$.

The rain shadow affects a lower precipitation at the southern end of any of the north easterly oriented valleys. Alexandra for example at the south end of the Manuherikia Valley has an annual mean of $346 \mathrm{~mm}$, whilst Falls Dam $55 \mathrm{~km}$ to the north in the same valley has $645 \mathrm{~mm}$. Precipitation in these valleys usually increases by $5 \mathrm{~mm}$ for every $\mathrm{km}$ northwards, and the west side generally has higher precipitation than the equivalent east. Virtually all of Central Otago has two thirds of the annual precipitation during the September to April growing season. Winter (June, July, August) is generally the driest season and late spring and summer the wettest.

\section{Mountain Ranges}

Information on mountain precipitation is limited and largely confined to observations in the Lammerlaw - Rock and Pillar and Old Main Ranges. Rainfall gradients rise steeply from the valley floors but because of the orientation of the ranges the precipitation gradient is steeper on the east than the west facing slopes (Table 2)

Table 2: Precipitation gradients on two aspects of the Rock and Pillar Range, Central Otago

Site
Patearoa

'Bliss and Mark (1974)

* MAF data

Precipitation on the Old Man Range also showed the winter minimum characteristic below $1000 \mathrm{~m}$, but not above, because of heavy winter snowfall (Mark 1965). Precipitation gradients (Table 3) in parts were as steep or steeper than those observed on Rock and Pillar escarpment.

Table 3: Approximate mean annual precipitation Old Man Range at $300 \mathrm{~m}$ intervals

\begin{tabular}{lccccc}
\hline Altitude $(\mathrm{m})$ & 300 & 600 & 900 & 1200 & 1600 \\
Precipitation $(\mathrm{mm})$ & 340 & 490 & 740 & 1180 & 1600 \\
Rainfall Gradient $\mathrm{mm} / 100 \mathrm{~m}$ & $\mathbf{C}$ & 50 & 83 & 147 & 140 \\
\hline
\end{tabular}




\section{The East Otago Plateau}

Precipitation gradients are negligible on the East Otago Plateau, the precipitation being a fairly uniform $500-600 \mathrm{~mm}$ where the plateau lies in the lee of the surrounding ranges or is below $1000 \mathrm{~m}$ altitude.

\section{WIND}

Wind speeds in Central Otago are strongly correlated with altitude and as a general rule wind speeds increase by $10 \%$ for every $100 \mathrm{~m}$ increase in altitude (Dawber and Edwards 1978).

For exposed sites the general relationship for the Otago region is:

Daily wind run in $\mathrm{km}=207+0.3$ (height of site in metres)

Although this relationship is generally true some lower sites in the lee of the ranges are strongly sheltered. Alexandra for instance is one of the calmest places in New Zealand with a mean daily wind run of $106 \mathrm{~km}$. For comparison Invercargill records 408 km/day; Dunedin Airport 312, Christchurch Airport 336, Blenheim 384, Wellington (Kelburn) 504 and Napier 192.

On exposed sites where the wind run is 400 to $500 \mathrm{~km} /$ day wind velocity is fairly uniform over most months of the year. This makes their winters most uncomfortable because of the increased chill factor. However, the lack of wind in the valley floors during winter makes Central Otago very tolerable, even with freezing temperatures. This extremity of conditions varies with the severity of the exposure of the site. The most vulnerable are sites in the Uplands of the East Otago Plateau with a coastal or southerly exposure. The strongest winds are usually NW or SW and the general coolness of the East Otago Plateau is in no small measure due to its southerly exposure, its proximity to the coast and cold rain bearing winds.

\section{Agricultural Significance of Temperature, Rainfall and Wind}

The long term trend towards increasing temperature could reverse unpredictably at any time and a cool period eventuate as from 1890 to 1900 . It is essential therefore that allowance is made for this in plant selection programmes, a point which is especially pertinent when the testing of germplasm aims at producing plants adapted to specific regions, environments and farming systems (Keoghan 1986). Should an annual $1{ }^{\circ} \mathrm{C}$ cooling occur plants selected for suitability at a given altitude may in fact be only suited to areas 300 metres lower in height. Many species in Otago are at their southern climatic limits and any attempts to diversify could be frought with failure by any decrease in temperature. An example of this is the East Otago Plateau which is at the marginal limits for wheat and barley production, some 290 GDD being needed for satisfactory maturity (Figure 3). If temperatures are cooler than normal, harvest will be late and almost impossible if heading is delayed until May with the possibility of snow storms.

If regionally adapted cultivars are going to be produced (Keoghan 1986) there is a marked need in Central Otago for more detailed climatic mapping. The positive temperature gradient in the warmer season means that inland sites can have a mean warm season temperature 2 to 3 degrees higher than sites at the same altitude nearer the east coast. The daily pasture production $150 \mathrm{~km}$ inland is therefore considerably higher than for coastal sites at equivalent altitudes. However the dormant season inland is longer than for coastal sites, and as a result of this the two factors counterbalance each other and annual pasture production is similar for both regions under a similar moisture regime.

When temperature, rainfall and wind are all taken into account the 600 to $900 \mathrm{~m}$ altitude zone is the most favourable for production and production development. Below $600 \mathrm{~m}$, in the absence of irrigation, moisture stress (or rainfall deficiency) is a problem; above $900 \mathrm{~m}$ temperatures are too low, and growing season is short $\mathbf{- 1 5 0}$ 


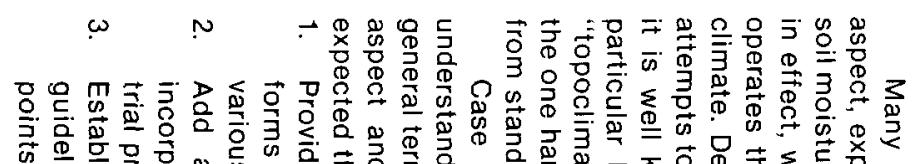

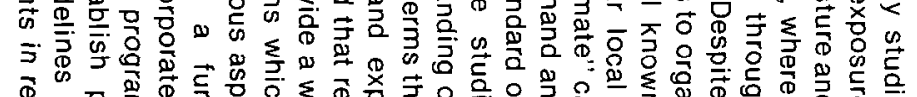

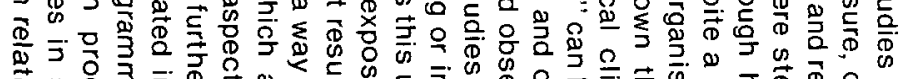

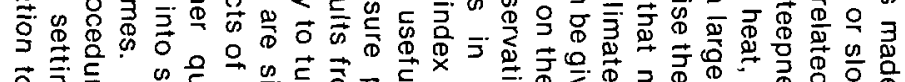

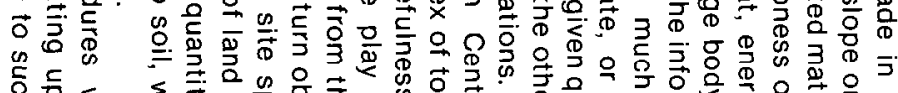

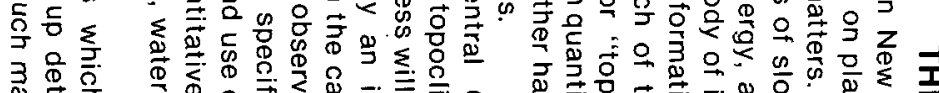

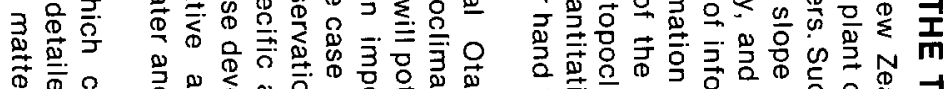

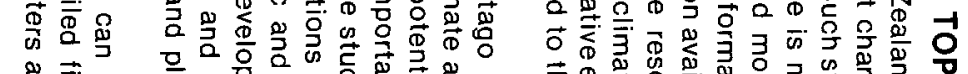

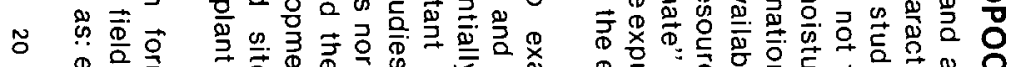

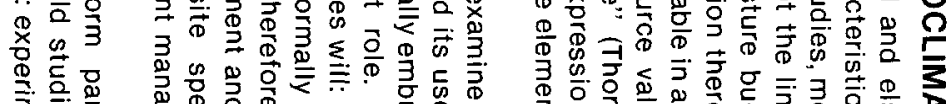

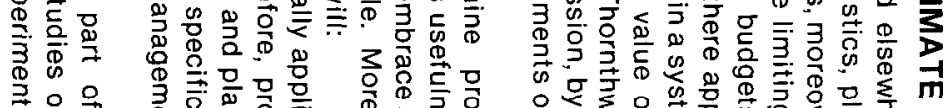

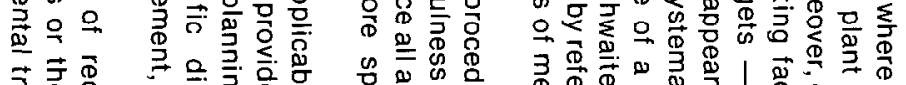

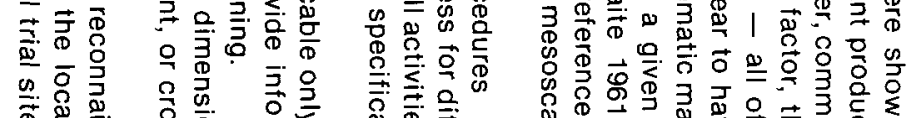

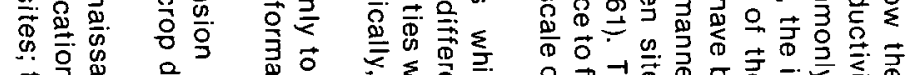

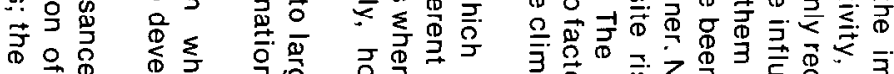

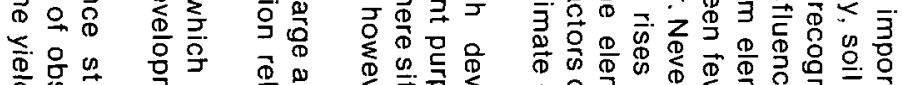

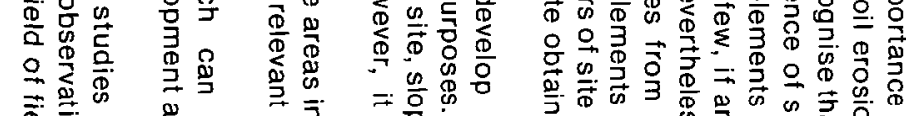

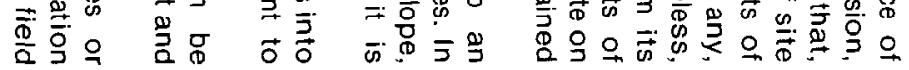

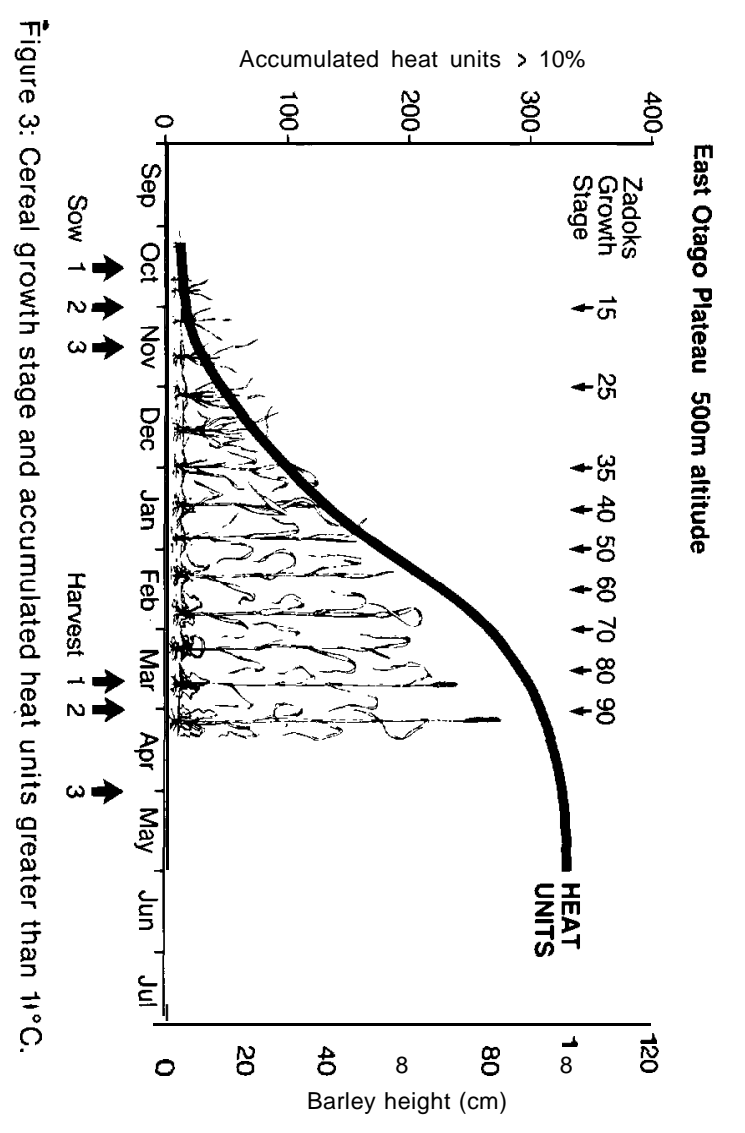


crops which lie in a microclimate in a region normally regarded as beyond the plant's climatic limit; hazard investigations and experiments, e.g. cold tolerance and plant winter damage; different aspects of development or nature conservation.

Case studies undertaken over the past two years by Invermay Agriculture Research Centre relate to two disparate agricultural activities. One study related to the Upper Clutha Valley and the technique although simple was sensitive to local conditions and showed the Upper Clutha Valley to be warmer than anticipated on many of the high terraces. The second study, on a more varied topography, included the Remarkable Mountains, the Old Man Range and the East Otago Plateau. This study was particularly aimed at assessing the climatic adaptability of a wide range of lotus and other grass and legume germplasm now under test for hill and high country farming. The outcome of these studies is the production of a topoclimatic map showing the relationship between soil, plant and climate. It is quite possible the mean value climate of horizontal surface observation, at a station, may apparently be unsuitable for a particular crop. However, taking into account the spatial variability, 5,10 or ever $20 \%$ of that region may have horizontal or sloping surfaces eminently suitable for that crop (Revfeim and Hurnard 1980). Cluster analysis of climatic and geographic data makes it possible to choose an environmentally typical location where variety trials can be conducted, even at the micro scale. The number of varieties tested can then be reduced to a minimum (Teuber et al. 1984). Such is the advantage of Topoclimatic mapping.

\section{Acknowledgement}

Climatic data, unless noted otherwise, are drawn freely from the New Zealand Meteorological Service Miscellaneous Publication Series.

References

Bliss L.C., Mark A.F. 1974. High alpine environments and primary production on the rock and pillar range, Central Otago. New Zealand. N.Z. Journal Botany 12: 445-483.

Browne M.L. 1959. Typical rainfall patterns over Central Otago. N.Z. Journal of Geology and Geophysics 21. 88-94.

Cossens G.G 1982. Effects of altitude on cereal. brassica, and grass growth in Otago. Proceedings Agronomy Society of New Zealand 12: 51.56 .

Dawber K.R., Edwards P.J. 1978. Otago wind energy survey. First Report. Otago University. Dunedin

Keoghan J.M. 1986. M.A.F. Research on alternative pasture species, cultivars and lines for southern South

Island hill and high country. Proceedings Hilland High Country Seminar 1985. Lincoln College. Canterbury 29.38.

Mark A.F. 1965. Vegetation and mountain climate. In Lister R.G. (Ed.) Central Otago. Special Publication N.Z Geographical Society Msc. Series No. 5. $195 \mathrm{pp}$.

Maunder W.J. 1965. Climatic character. In Lister R.G. (Ed.) Central Otago. Ibid. 195 pp.

N.Z. Meteorological Service. N.Z. Meteorological Service Misc. Publications 159, 177. 183. 185, 186, 187.

Revfiem K.F.A., Hurnard S.J. 1980. Pasture, pumpkins, persimmons or pines - the use of weather information in planning plant and animal performance in the 1980s. NZ Agricultural Science 14: 160-162.

Salinger M.J., Gunn J.M. 1975. Recent climatic warming around New Zealand. Nature, 256 396-8.

Teuber Larry R. ef al. 1984. Climate and dormancy data reduce need for many regional alfalfa trials. California Agriculture $38,5 \& 6.12-16$

Thornthwaite C.W. 1961. The task ahead. Annals Association American Geographers 51, 345-356.

Trenberth K.E. 1977. Climate and climatic change. A New Zealand perspective. 51 p. N.Z Meteorological Service Misc. Publication 167. 